\title{
ДІЯЛЬНІСТЬ ІРЦ У СИСТЕМІ ПІДТРИМКИ ДІТЕЙ 3 ОСОБЛИВИМИ ОСВІТНІМИ ПОТРЕБАМИ: АКТУАЛЬНІ ПИТАННЯ
}

Світлана Литовченко, Інститут спеціальної педагогіки і психології імені Миколи Ярмаченка Національної академії педагогічних наук України, м. Київ, svetalitovchenko@ukr.net

Розглянуто сучасні підходи до надання послуг дітям з особливими освітніми потребами, представлено основні напрями роботи фахівців у межах діяльності Інклюзивно-ресурсних центрів, 3 огляду на їх інноваційність для України. 3 практичного досвіду запропоновано апробовані рекомендації узагальнення результатів оцінювання та підготовки висновку, що сприятиме ефективній організації роботи.

Ключові слова: діти з особливими освітніми потребами, Інклюзивно-ресурсний центр, комплексна оцінка розвитку, висновок IPЦ.

Литовченко Светлана, Институт специальной педагогики и психологии имени Николая Ярмаченко НАПН Украины, г. Киев, svetalitovchenko@ukr.net.

Деятельность ИРЦ в системе поддержки детей с особыми образовательными потребностями: актуальные вопросы

В статье рассмотрены современные подходы к предоставлению услуг детям с особыми образовательными потребностями, представлены основные направления работы специалистов в рамках деятельности инклюзивного-ресурсных центров, учитывая их инновационность для Украины. Из практического опыта предложено апробированы рекомендации обобщения результатов оценки и подготовки заключения, что будет способствовать эффективной организации работы.

Ключевые слова: дети с особыми образовательными потребностями, инклюзивноересурсный центр, комплексная оценка развития, вывод ИРЦ.

Svitlana Lytovchenko, Mykola Yarmachenko Institute of Special Education and Psychology of The National Academy of Educational Sciences of Ukraine, Kyiv, Ukraine.

IRC Activities in Supporting Children with Special Educational Needs: Topical Issues

The article examines modern approaches to providing services to children with special educational needs, the main directions of work of specialists within the activity of InclusiveResource Centers, in view of their innovativeness for Ukraine. Practical experience offers proven recommendations for generalizing the results of assessment and preparation of the conclusion, which will facilitate efficient organization of work.

Keywords: children with special educational needs, Inclusive Resource Center, comprehensive development assessment, ICC conclusion. 
«Якщо ви займаєтесь роботою, яку любите - вона відповість взаємністю. Все інше прийде»

(з мережі Інтерент)

Вступ. Упровадження міжнародних стандартів професійної допомоги дітям з особливими освітніми потребами, визнання прогресивної соціальної моделі інвалідності, за якої обмеження розглядаються як результат дискримінації $з$ боку суспільства, а не стану людини (наприклад, глухота не виступає порушенням («інвалідністю»), натомість можливістю доступу до самобутньої культури та мови), започаткування діяльності мережі нових для нашої країни установ - Інклюзивно-ресурсних центрів (ІРЦ), а відтак здійснення покладених на них функцій на сучасних концептуальних засадах зумовлюють потребу в розробленні механізмів проведення комплексної психолого-педагогічної оцінки розвитку дитини та забезпечення системного кваліфікованого супроводу.

Необхідно відзначити, що в Україні інклюзивно-ресурсні центри розпочали свою роботу з 2018 р., за даними МОН України на листопад 2019 р. кількість зареєстрованих центрів становила 603, до кінця 2020 р. планують відкрити ще 96. Сучасний період - час становлення діяльності ІРЦ, які розглядають як першу ланку на шляху навчання дитини з особливими освітніми потребами. Нині наявна нормативна база [1], на яку ми спираємося, розроблено теоретичні та організаційні основи [3], доступні зарубіжні джерела, водночас практики недостатньо, існують дискусійні питання, такі, що потребують досвіду. Насамперед фахівцям ІРЦ необхідно опанувати нові знання, відпрацювати алгоритми, протоколи, технології вирішення завдань на кожному етапі супроводу дитини, які являють собою певну інновацію, потребують відповідної апробації.

Тому, виникає потреба у проведенні емпіричних розвідок, узагальненні результатів, а також розробці тих компонентів діяльності ІРЦ, дефіцит яких негативно впливає на весь процес супроводження.

У контексті проблеми зауважимо: в Україні вже діє «Міжнародна класифiкація функціонувания, обмеження життєдіяльності $i$ здоров'я. Діти $і$ підлітки» (МКФ-ДП), що дає розуміння про функціонування дитини в різних контекстах; основні ідеї, підходи МКФ покладено в основу діяльності ІРЦ, зокрема й процедури оцінювання та оформлення висновку. У 2018 р. МОН України закупило стартовий пакет методик для оцінювання особливих освітніх потреб на базі ІРЦ. Це світовий стандарт діагностики (діагностування лише в контексті визначення особливостей), необхідність доказової бази досліджень, стандартизації інструментів і є свідченням інтеграції України у світове співтовариство. Як зазначають експерти, методики обирали через процентне співвідношення порушень, які трапляються у дітей від 1 до 16 років (розлад дефіциту уваги та гіперактивність; розлади аутистичного спектра; дислексія, дисграфія, дискалькулія). На сайті МОН України розміщенні відео презентації про діяльність ІРЦ.

Розглянемо рекомендації та ідеї щодо узагальнення результатів оцінювання, технології оформлення висновку ІРЦ, як важливого напряму діяльності фахівців ІРЦ.

«ОСОБЛИВА ДИТИНА: навчання і виховання», № 4, 2019 
Висновок про комплексну психолого-педагогічну оцінку розвитку дитини [1] документ, який містить інформацію щодо індивідуальних особливостей розвитку дитини, їі особливих освітніх потреб, рекомендації членам команди супроводу, перелік необхідних психолого-педагогічних послуг; розробляється фахівцями ІРЦ за результатами комплексного оцінювання та є основою для складання Індивідуальної програми розвитку (ІПР).

У Висновку про комплексну оцінку зазначають:

Умови виховання в сім'ї. Заповнюється відповідно до результатів бесіди $з$ батьками (законними представниками), інформації соціального педагога. Важливо уточнити моменти, які є суттєвими щодо організації освітнього процесу, зокрема: інформація про склад сім'ї, членів родини, які надаватимуть дитині підтримку вдома (сім'я повна / неповна; інші члени родини); якою мовою спілкуються в родині (наприклад: «у родині спілкуються вірменською мовою» / «українською жестовою мовою», «користуються дактилем, українською жестовою мовою», «жестомовна родина»,); наявність умов для проведення занять 3 дитиною вдома, якщо такі потрібні. Пропозиції: за формою Висновку зазначається дата народження батьків (законних представників), їх рівень освіти, місце роботи та посада; на нашу думку, ці дані не інформативні, думка про те, що рівень освіти, більш «престижні» професії чи посади свідчать про можливість батьків більш якісно підтримувати дитину вдома - застарілі, відтак ї можна вилучити, натомість додати контактний номер телефону.

Стан здоров'я дитини. Важливою є інформація щодо часу виникнення порушення / віку, в якому воно діагностовано; виду, часу та якості заходів з компенсації / корекції (слухопротезування тощо). Підтримуємо думку про те, що інформація щодо діагнозів має міститися у пакеті медичних документів, які зберігаються у медичному кабінеті. Це значно розширюе сферу застосування висновку, зокрема, батьки можуть надати його до закладу позашкільної освіти, який відвідує дитина, тощо. На перших етапах роботи ІРЦ до висновку вносилися дані щодо анамнезу дитини (інформація про вагітність, пологи тощо), що викликало зауваження з боку батьків; на сьогодні у цьому пункті зазначають: «Виписка 3 істоpiї розвитку дитини додається до основних документів».

Напрями проведення комплексної оцінки. Оцінку здійснюють відповідно до основних сфер розвитку дитини (фізична, мовленнєва (мовленнєво-комунікативна), когнітивна, емоційно-вольова) та навчальної діяльності, у межах яких визначають компетенції, потреби та рекомендації [2] (у разі необхідності фахівці проводять комплексну оцінку за іншими напрямами, зокрема визначення рівня соціальної адаптації, взаємовідносин з однолітками, дорослими).

Важливим при узагальненні результатів комплексної оцінки є спрямування на визначення сильних сторін дитини, зокрема здібностей, знань, умінь, навичок та інтересів, які в подальшому стануть опорою для надання підтримки.

У графі «Компетенція» зазначається чи відповідають виявлені показники розвитку дитини віковим особливостям. Якщо дитина за певною сферою не має особливих потреб, пропонуємо зазначити коротко «Компетенції в цілому відповідають віковим особливостям (віковим нормам)»; відповідно у графі потреби: 
«Немає особливих освітніх потреб», рекомендації сформулювати приміром як «Загальні рекомендації з розвитку мовлення для дітей старшого дошкільного віку (читання художньої літератури, переказ, вивчення віршів тощо)». Натомість для дітей зі суттєвим ступенем порушення / складними порушеннями розвитку доцільно максимально деталізувати інформацію.

За виявленими труднощами в будь-якій зі сфер розвитку та навчальній діяльності визначаються особливі освітні потреби. Відповідно до сучасного розуміння потреба [3] передбачає додаткову тимчасову чи постійну підтримку, яка реалізується через відповідні корекційно-розвиткові послуги, спеціальне обладнання, наявність асистента вчителя та/або асистента дитини, необхідні адаптації та/або модифікацій в освітньому процесі.

Наприклад, дві дитини з однаковим ступенем порушення слуху на етапі вступу до школи можуть мати зовсім різні потреби, різний рівень функціонування (відповідно до МКФ): для однієї (за умови вчасного виявлення порушення, оптимального слухопротезування, фахового супроводу) потрібно лише дотримання принципів універсального дизайну, іншій - підтримка в освітньому процесі у формі супроводу жестовою мовою. Біологічні чинники мають значення, але вони не є визначальними щодо участі дитини в освітньому процесі.

Потреби мають бути задоволенні у процесі освітньої діяльності шляхом (при наданні) відповідних рекомендащій. Загальні типи адаптацій навчальних завдань та приклади особливостей адаптації для різних дітей з особливими потребами представлено у посібнику: Данілавічюте Е. А., Литовченко С. В. (2012) Стратегії викладання в інклюзивному навчальному закладі. Навчально-методичний посібник // за заг. ред. Колупаєвої А. А. - К. : Видавнича група «А.С.К.», 2012. 335 с. - (Серія «Інклюзивна освіта»).

Пропозищї: комплексна оцінка проводитися за всіма напрямами; до висновку вносяться результати за тими напрямами (напрямом), у межах яких було виявлено труднощі та визначено наявність особливих освітніх потреб; можливо ввести таке формулювання: «Оскільки, за результатами оцінки розвитку фізичної, емоційно-вольової сфери не було виявлено труднощі, компетенції загалом відповідають віковим особливостям, результати за цими сферами до Висновку не внесені».

Загальні висновки включають інформацію про наявність/відсутність особливих освітніх потреб [4], необхідні психолого-педагогічні послуги; рекомендації для педагогічних працівників та батьків (одного з батьків) або законних представників; дату, мету та напрями повторної оцінки (необхідність планової повторної оцінки визначається фахівцями ІРЦ з метою констатації динаміки розвитку дитини, визначення рівня задоволення потреб, розгляду доцільності зменшення обсягу додаткових послуг тощо; така оцінка не є обов'язковою).

Складання висновку - командна робота. Фахівці ІРЦ зазначають у висновку результати комплексної оцінки за напрямами (результати оцінки розвитку фізичної сфери зазначає вчитель лікувальної фізкультури; мовленнєвої сфери вчитель-логопед; когнітивної та емоційно-вольової сфер - практичний психолог; навчальної діяльності - учитель дефектолог); висновки та рекомендації форму-

«ОСОБЛИВА ДИТИНА: навчання і виховання», № 4, 2019 33 
ються на основі узагальнення результатів оцінки. Важливо: рекомендації ІРЦ мають бути спрямовані на створення сприятливого середовища для гармонійного розвитку дитини, основною кінцевою метою є не визначення окремих напрямів допомоги, а створення комплексної системи роботи.

Одним із сучасних принципів реабілітації є орієнтація фахівців для надання допомоги сім'ї, широке залучення батьків до роботи з дітьми та підвищення відповідальності батьків за реабілітацію та навчання своїх дітей, адже батьки $є$ основними замовниками освітніх послуг; їм надано право вибору закладу освіти для своєї дитини, відповідно вони мають бути готові зробити правильний вибір та усвідомлювати свою роль у процесі здобуття освіти дитиною; батьки мають бути максимально залученні до освітнього процесу.

Фахівці ІРЦ зобов'язані ознайомити батьків / одного з батьків або законних представників дитини з Висновком, умовами навчання та надання психолого-педагогічних послуг у закладах освіти (у разі здобуття дитиною дошкільної чи загальної середньої освіти). Батьки / один з батьків або законні представники підписують Висновок, де зазначено, що вони «з Висновком ознайомлені»[5]. Важливо, щоб батьки / один з батьків або законні представники були детально проінформовані про результати оцінювання; повідомлення результатів має відбуватися за відсутності дитини (дитина не має чути); з дотриманням норм коректності (недопустимі звинувачування батьків, ситуації, що змушують іх виправдовуватися). Водночас, батьки / один з батьків (законні представники) мають усвідомлювати, що рекомендації фахівців, психолого-педагогічна послуги є необхідними та обов'язковими для розвитку та здобуття освіти іхньої дитини.

Пропозищї: в межах консультативної допомоги після надання Висновку важливо підтримувати зворотній зв'язок з батьками дитини (через певний час фахівець ІРЦ має зв'язатися з ними, з'ясувати важливі питання щодо місця навчання, послуг, наявності потреби у співпраці з ІРЦ). Детальна інформація для батьків щодо особливостей оформлення Висновку (роз'яснення, відповіді на питання, які часто зустрічаються) має бути розміщена на сайті ІРЦ, введена до інформаційних бюлетенів. Приклади з досвіду: під час оцінки в ІРЦ батьки демонструють відео, на якому дитина проявляє себе у звичному для неї оточенні (розповідає, відповідає на запитання, декламує вірш чи співає, грається, виконує навчальні інструкції, побутові дії тощо), фото із їі виробами; приносять іграшки (дидактичні матеріали), з якими дитина звикла гратися та/або займатися (наприклад, хлопчик М. демонстрував уміння показувати названий колір з допомогою «Сортера», з яким він займається вдома - повертав доверху бік іграшки правильного кольору, натомість із «незнайомими» матеріалами відмовлявся працювати); діти (шкільного віку) також демонструють фото своїх виробів чи друзів, коментують, що створює позитивну атмосферу, дає можливість дізнатися про відносини з однокласниками; на етапі написання заяви, варто запитати у батьків про деталі організації проведення комплексної оцінки (наявність у кімнаті іграшок, дидактичних матеріалів (чи не відволікатимуть), оптимальна кількість дорослих, особливості спілкування з братиками /сестричками (наприклад, одночасно чи по черзі); альтернативні засоби комунікації, зручні меблі тощо). 


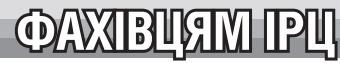

Такий талон-нагадування про дату та час оцінки приятиме створенню «атмосфери довіри»:

\begin{tabular}{|c|c|}
\hline \begin{tabular}{l} 
Інклюзивно-ресурсний центр № 3 \\
Деснянського району \\
вул. Братиславська, 14-А \\
\multicolumn{1}{l}{ Проведення комплексної оцінки } \\
Дата \\
Час \\
Співробітник \\
тел.
\end{tabular} & $\begin{array}{c}\overline{ } \\
\text { 3а бажанням візьміть творчі роботи дитини, } \\
\text { відзнаки у конкурсах, змаганнях тощо. } \\
\text { Будемо раді співпрацювати з Вами та Вашою } \\
\text { дитиною! }\end{array}$ \\
\hline
\end{tabular}

Значущість інформації, яка містяться у Висновку полягає в тому, що вона є основою рекомендацій для команди супроводу, що буде працювати з дитиною, батьків / одного з батьків або законних представників та створення безбар'єрного середовища.

Рекомендащії щодо заповнення Висновку: для оформлення варто використовувати лаконічну «просту» мову, загальновживану психолого-педагогічну термінологію; висновок є інструментарієм для організації навчальної та корекційнорозвиткової роботи, має бути максимально практичним; за висновком педагоги організовують освітній процес та оцінювання навчальних досягнень дитини.

Наступний аспект - суттєвий у контексті проблеми. На жаль, на сьогодні фінансування і / або можливість отримати допомогу в умовах інклюзії, зазвичай, залежать від того, чи відповідає дитина вимогам діагностичних категорій, визначених у процесі оцінювання. Згідно з сучасними нормативами категорійні поняття обмежених можливостей залишаються тісно пов'язаними 3 економічними чинниками, оскільки школи та інші заклади отримують фінансування лише залежно від виявлених у дітей обмежених можливостей. Наприклад, існує певний перелік порушень, які «підпадають під інклюзивну форму навчання», до цього переліку не внесені діти із гіперактивністю та дефіцитом уваги («поведінкові проблеми», «невидимі» порушення), які часто потребують додаткової підтримки в умовах закладу освіти. Заради справедливості зазначу, що про таку проблему писали і закордонні колеги (Clapton\&Fitzgerald, 1997; Jordon, 2001: Meyer, 2001); йдеться про «модель фахової допомоги», за якої робота 3 дітьми характеризується зосередженням на діагнозі.

Одне із найболючих питань діяльності ІРЦ пов’язане з бажання батьків, які звертаються до ІРЦ, аби їні діти навчалися саме у логопедичних групах (при цьому діти мають потреби також у підтримці корекційних педагогів, у деяких випадках - асистентів вихователя чи асистентів дитини, адаптацій у роботі вихователів).

Фахівці ІРЦ та логопеди-«дошкільники» у своїх консультаціях звертають увагу батьків, що дитині потрібна додаткова підтримка, відповідні заняття, варто використати дуже цінний дошкільний вік, щоб підтримати дитину і відповідно на етапі шкільного навчання - вона мала мінімальні потреби, або зовсім не потребувала «особливої уваги». Проте батьки обирають логопедичні групи тому що - маленькі (на відміну від інклюзивних), відносно велика кількість і 
відповідно наближеність до дому, а заняття з корекційним педагогом чи іншими фахівцями (фахівцями 3 роботи 3 дітьми 3 аутизмом тощо) планують організовувати приватним чином.

Звичайно, ситуації потрібно вирішувати, передусім на користь дітей. Можливо доцільно ввести посаду вчителя-дефектолога (корекційного педагога) до штату садочків, де є логопедичні групи (заняття проводитимуться відповідно до рекомендацій ІРЦ, півроку-рік, за потреби). Можливо, окрім традиційних груп для дітей із ЗНМ, ФФНМ відкривати ще «групи підтримки» (над назвою можна подумати), де були б дітки, які потребують підтримки не лише логопедів. Зарубіжний досвід свідчить, що найкращий варіант, коли дитина отримує необхідні послуги за місцем навчання.

Фахівці ІРЦ мають визначати яка підтримка потрібна дитині й відповідно до потреб передбачити можливість посади асистентів вихователів у логопедичних групах.

I звичайно співпрацювати з батьками, завойовувати їх довіру, адже зрозуміло, що батьки перші, хто хочуть для дитині найкращого. Гнучкість підходів на часі.

Перспективи подальших досліджень. Стаття не висвітлюе проблему діяльності ІРЦ повною мірою, представляє найбільш актуальні їі аспекти. Зокрема, надзвичайно важливим $є$ вивчення міжнародної практики, саме країни північної Америки, які мають тривалу історію та значні успіхи щодо інклюзивного навчання дітей з особливими потребами, залучення національних надбань спеціальної педагогіки і психології.

\section{ЛITEPATУPA}

1. Положення про інклюзивно-ресурсний центр// [Електронний ресурс]. - 2017. - Режим доступу:https://zakon.rada.gov.ua/laws/show/545-2017-\%D0\%BF.

2. Колупаєва А. А., Данілавічютє Е. А., Литовченко С. В. Професійне співробітництво в інклюзивному навчальному закладі: навчально-методичний посібник. - К.: Видавнича група «А.С.К.», 2012. - 197 с. (Серія «Інклюзивна освіта»).

3. Організаційно-методичні засади діяльності інклюзивно-ресурсних центрів: навчальнометодичний посібник / За заг. ред. М. А. Порошенко та ін. - Київ: 2018. - 252 с.

4. Canadian Association of the Deaf. - Режим доступу: http://cad.ca.

\section{REFERENCES (TRANSLATED AND TRANSLITERATED)}

1. Polozhennya pro inklyuzivno-resursniy tsentr [Internet]. Availablefrom: https://zakon. rada.gov.ua/laws/show/545-2017-\%D0\%BF.

2. Kolupayeva A. A., Danilavichyutye E. A., Lytovchenko S. V. Profesiynespivrobitnytstvo v ink lyuzyvnomunavchalnomuzakladi. Kyiv: Vydavnychagrupa «A.S.K.»; 2012. 197 s. [InUkrainian].

3. Poroshenko M. A., editors. Organizatsiyno-metodichni zasadidiyalnosti inklyuzivnoresursnikh tsentriv: navchalno-metodichniy posibnik. Kiyiv; 2018. 252 s.[InUkrainian]. 